\title{
Multiphase Interleaved Bidirectional DC-DC Converter for Electric Vehicles and Smart Grid Applications
}

\author{
A. Sahbani ${ }^{1,2}$, K. Cherif ${ }^{2}$, K. Ben $\operatorname{Saad}^{2}$ \\ ${ }^{1}$ Medina College of Technology Al Madinah Al Munawwarah, Kingdom of Saudi Arabia \\ ${ }^{2}$ Laboratory of Automatic (LARA) \\ National Engineering School of Tunis, Tunis El Manar University \\ BP37, 1002 Tunis, Tunisia \\ (abdellazizsahbani@yahoo.fr, a.sahbani@mct.edu.sa)
}

Received: 01.05.2020 Accepted:25.06.2020

\begin{abstract}
This paper deals with the design and the control of multiphase interleaved bidirectional DC-DC Converter. This converter is used for Electric Vehicle (EV) applications to convert and increase energy storage system voltage from low side voltage to high side voltage, which is necessary to feed the inverter used to drive the traction motor. The proposed converter can be used to connect the energy storage system to the smart grid. To increase the performance of high side voltage and to have equal sharing of the load current in each converter module a Fuzzy sliding mode control is proposed. The control method is tested by simulation for the case of 4 interleaved bidirectional DC-DC Converter associated with the three phase inverter coupled with a 3 phase induction motor. The simulation results proved the robustness of the proposed control method under some disturbances.
\end{abstract}

Keywords- Bi-directional DC-DC converter, Smart grid, Fuzzy sliding mode control, Robustness, Electric Vehicle, Traction motor, three phase inverter.

\section{Introduction}

Bi-directional DC-DC power converters have an important role to control the power of an electric vehicle. The bidirectional DC-DC manages power flow between the smart grid and the energy storage system and the high voltage propulsion bus. The converter works in boost mode when the power flows from the battery to the high voltage propulsion system and it works in buck mode when charging the battery [1].

We find different topologies in literature, the bidirectional DC-DC converter can be isolated [2-6] and non-isolated [7-13]. By comparison with the simple structure, the non-isolated bidirectional DC-DC converters have several advantages such as, high efficiency, low cost, etc. In [9], the authors use a full-bridge DC-DC converter. In [10-15] a half-bridge bidirectional DC-DC converter is presented.

In traction application especially in an Electrical Vehicle (EV) the converter is used in a high power and low-voltage conditions which generate currents in the order of hundreds of Amperes. These big currents increase the loses in the active and the passive converter components. Moreover, theses loses can reduce the converter efficiency [16].
Due to the high currents generated in some EV converters, some methods use the interleaving technique. In recent years, the interleaving techniques have been widely used in high current DC-DC converters and the current ripple of the total current after interleaving will be minimized.

The interleaving multiphase bidirectional DC- DC converter has been extensively used in EV in order to increase the power density, with minimized inductance [17-21].

In [22- 24] the authors showed that using N parallel DC-DC converter with the interleaving technique has some advantages. Such technique eases the maintenance and the repair of the system. Moreover, the sharing of the current can decrease the ripple in the load current and can reduce the switching and conduction losses. Additionally, the seize and losses of the filtering stage (inductors and capacitors) are reduced and the converter dynamic response is improved [24]. Using a high number of phases offers other advantages. Indeed, power components can be Surface Mounted Devices (SMD) and the filters can be integrated in the PCB. In [23-24] the authors present a comparison between the multiphase DC-DC converters with single-phase ones to highlight the advantages of using the multiphase converter. 
For the non-isolated high-power multiphase bidirectional DC-DC converters used in hybrid and electric vehicle energy systems were found in two-phase [25], [33], three-phase [4] [27], [29], [30] and more [22], [17], [27].

The control of the output voltage must be made in a closed loop control mode. For this purpose, several control methods have been proposed [1] [28-31]. There are many methods to achieve current sharing among different converters modules [20-], [22] [28], [32-35]. One of the most popular methods is current sharing method with current-mode control [32- 33]. However, these techniques present some limitations.

Nonlinear control methods have been designed to offer stable regulation of the output voltage and equal sharing of the load current in each module [34-36].

This paper is organized as follows. In section 2, the structure of a multiphase bi-directional DC-DC converter is proposed. Then, the inverter and the traction motor model are presented. The Fuzzy sliding mode control is described in section 3. The simulation results are given and discussed in section 4 .

\section{System description}

In this section, we present the traction system of EV. As shown in Figure 1, the power conversion systems type [29-36] uses a low voltage battery, an interleaved bidirectional DC-DC converter to boost the battery voltage from low voltage to high voltage and to feed three-phase inverter which is used to drive the traction motor.

For the traction motor we can use a Permanent Magnet Synchronous Motor (PMSM) [31] [45], an induction motor [41] [42], a brushless DC motors [37] or Switched Reluctance Machine [38]. The choice of the motor depends on the control technology, the torque, the power density and the cost.

The design of each component of an EV traction system is discussed in the following.

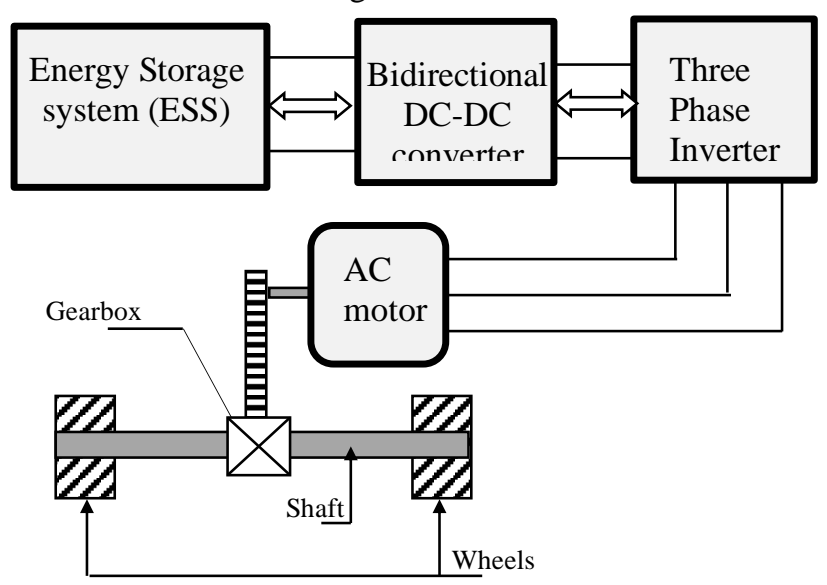

Fig. 1. EV traction system

\subsection{Structure of bi-directional $D C-D C$ converter}

Figure 2 presents a half-bridge converter operating in two quadrants of (voltage-current) plane. Therefore, voltage is positive and current can be positive or negative.

The structure of the converter consists of two controlled switches $\left(s w_{1}\right.$ and $\left.s w_{2}\right)$, two diodes $\left(D_{1}\right.$ and $\left.D_{2}\right)$, an input filter capacitor $\left(C_{\text {in }}\right)$, an output filter capacitor $\left(C_{o}\right)$, a filter inductor $(L)$ and its equivalent series resistors $\left(r_{L}\right)$.

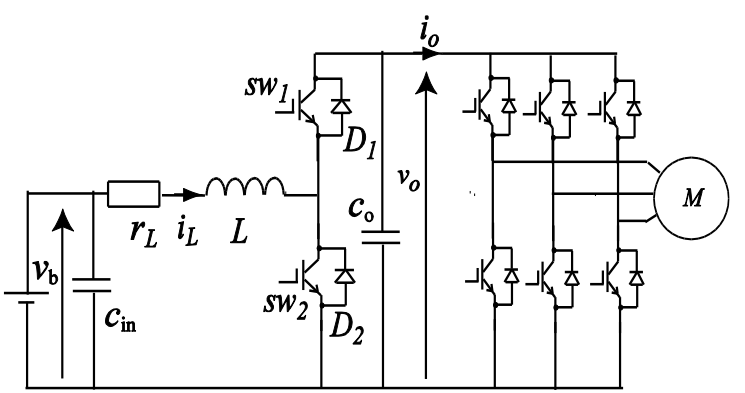

Fig. 2. Structure of bi-directional DC-DC converter

This converter is able to increase the battery voltage from low voltage to high voltage to feed the inverter and the traction motor. It is able to work in the reverse direction for the case of a regenerative braking state.

The bidirectional DC-DC converter is a combination of two basic DC-DC converters connected in antiparallel [ 10-11] [29]; a boost converter when power flows from the battery to the DC link (driven state) and a buck converter when power flows from the DC link to the battery (regenerative braking state).

During the driven state (boost mode) the bidirectional converter is used to step up the battery voltage, switchsw $w_{1}$ and $D_{2}$ are in conduction state according to PWM state but switch $s w_{2}$ and $D_{1}$ are in OFF state all the time. During regenerative braking state (buck mode), switch $s w_{2}$ and $D_{1}$ are in conduction state according to PWM state too and switch $s w_{1}$ and $D_{2}$ are in OFF State all the time.

The choice of the state vector $x=\left[\begin{array}{l}i_{L} \\ v_{o} \\ v_{b}\end{array}\right]$ allows the establishment of the following state space representation:

$$
\begin{aligned}
\dot{x}=\left[\begin{array}{ccc}
-\frac{r_{L}}{L} & -\frac{(1-\mathrm{d})}{L} & \frac{1}{L} \\
\frac{(1-\mathrm{d})}{C_{o}} & 0 & 0 \\
-\frac{1}{C_{i n}} & 0 & 0
\end{array}\right] x \\
+\left[\begin{array}{cc}
0 & 0 \\
-\frac{1}{C_{o}} & 0 \\
0 & \frac{1}{C_{i n}}
\end{array}\right]\left[\begin{array}{l}
i_{o} \\
i_{b}
\end{array}\right]
\end{aligned}
$$

$d$ takes 1 for the ON state of the switcher and 0 for the OFF state and :

$$
v_{b} i_{L}=\mathrm{v}_{o} i_{o}
$$




\subsection{Structure of the studied multiphase phase interleaved bi- directional DC-DC Converter}

In this section, we present the bidirectional DC-DC converter built in multiphase structure. Figure 3 shows the structure of a multiphase bidirectional DC-DC converter. The converter consists of a $2 \mathrm{~N}$ controlled switches $\left(s W_{11} \ldots s W_{N_{1}}\right.$ and $\left.s W_{12} \ldots s W_{N 2}\right), 2 \mathrm{~N} \operatorname{diodes}\left(D_{11} \ldots D_{N_{1}}\right.$ and $\left.D_{12} \ldots D_{N 2}\right), \mathrm{N}$ inductors $\left(L_{1}, L_{2} \ldots L_{N}\right)$ and their respective equivalent series resistors $\left(r_{1}, r_{2} \ldots r_{N}\right)$, an input filter capacitor $\left(C_{\text {in }}\right)$, an output filter capacitor $\left(C_{0}\right)$.

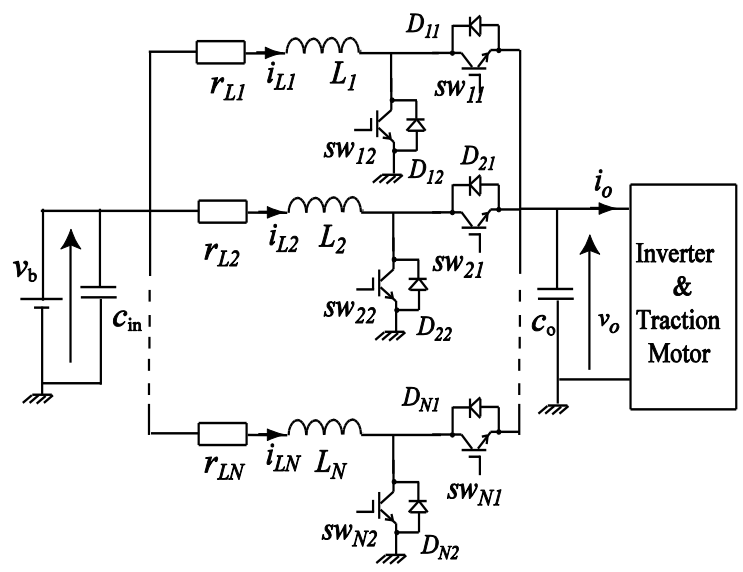

Fig. 3.Structure of N multiphase DC-DC converter

The structure of multiphase converters allows the shring of the current between several elementary cells. The current through each cell is then less important. The structure is essentially used to reduce the current ripple, the weight and volume of the converter. The individual converters are identical and the current throw each converter is:

$$
i_{L_{n}}=\frac{i_{L}}{q}
$$

The control commands of the switching cells have the same duty ratio. Assuming that the controlled switch of the cell number 1 begins at the initial time, the cell number $\mathrm{n}$ will be at the time $t_{n}=(n-1) \frac{T}{N}$

The current in each phase has a triangular ripple which is expressed by:

$$
\Delta i_{L_{n}}=\frac{v_{b}(1-d) \cdot d}{L \cdot f_{S W}}
$$

$$
\Delta i_{o}=\frac{v_{b}(1-N d) \cdot d}{L \cdot f_{S W}}
$$

where, $\mathrm{N}$ is the number of interleaved the bidirectional DC-DC converter, $f_{s w}$ is the switching frequency and $d$ is the duty ratio.

For duty ratio $(\mathrm{d})=0.5$ we obtain the maximum inductor current ripple.

Figure 4 shows that the output ripple current is reduced by increasing the number of bidirectional DC-DC converter converters cells.

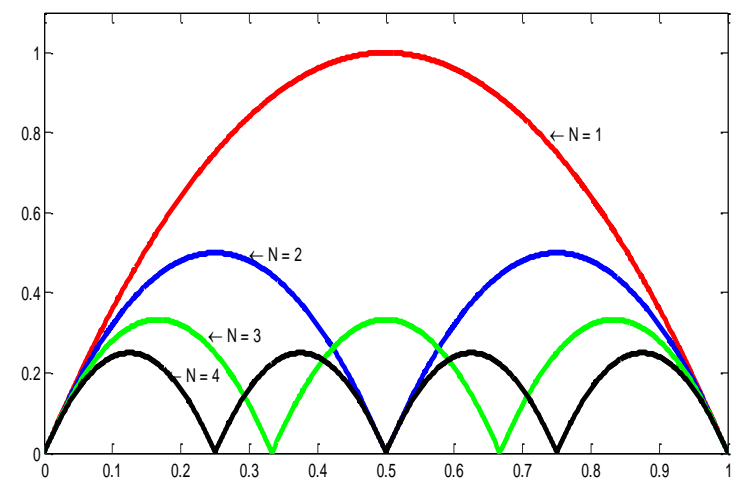

Fig. 4.Output ripple current

\subsection{Inverter Modeling}

The inverter consists of six-controlled switches, and it allows to convert the high side DC voltage into balanced threephase AC voltage. The six-switch are controlled through a Pulse Width Modulation (PWM) signal in order to carry the output voltage at preferred voltage and frequency and to minimize the output voltage signal harmonic. To generate the PWM signals we can use sinusoidal PWM, hysteresis-band current control or Space Vector Pulse Width Modulation Technique (SVPWM).

To control the AC motors the SVPWM is wildly used. It produces a constant switching frequency and a regulation of the frequency and the amplitude of output voltage. The SVPWM reduces the output current and voltage harmonic distortions. The SVPWM can be easily implemented in digital signal processor [39-42].

Figure 5 represents the circuit diagram of the three-phase voltage source inverter (VSI) using six IGBTs. We can notice that the upper switches $\left(Q_{1}, Q_{3}\right.$ and $\left.Q_{5}\right)$, and the lower ones $\left(Q_{2}\right.$, $Q_{4}$ and $\left.Q_{6}\right)$ are complementary switched. The control technique is composed of eight working states. Fig.6 shows the eight voltage vectors composed of six active vectors $\left(\mathrm{V}_{1}, \mathrm{~V}_{2}, \mathrm{~V}_{3}, \mathrm{~V}_{4}\right.$, $\mathrm{V}_{5}, \mathrm{~V}_{6}$ ) separated with 60 electrical degrees to form the axes of a hexagon and at the origin two zero voltages vectors $\left(\mathrm{V}_{0}\right.$ and $\left.\mathrm{V}_{7}\right)$.

The output current ripple is expressed by: 


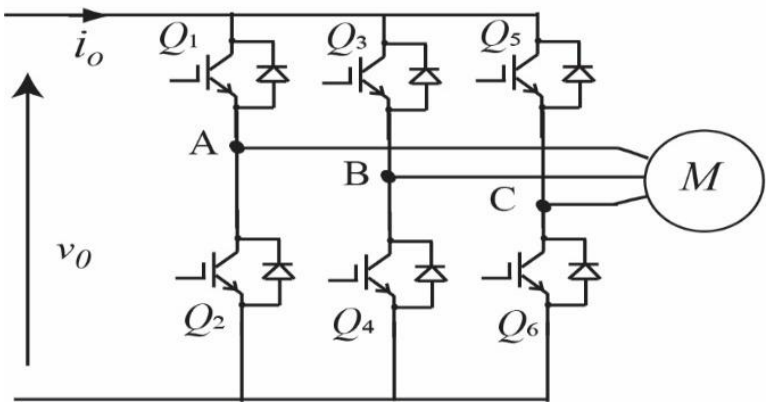

Fig. 5.Circuit diagram of the three-phase VSI

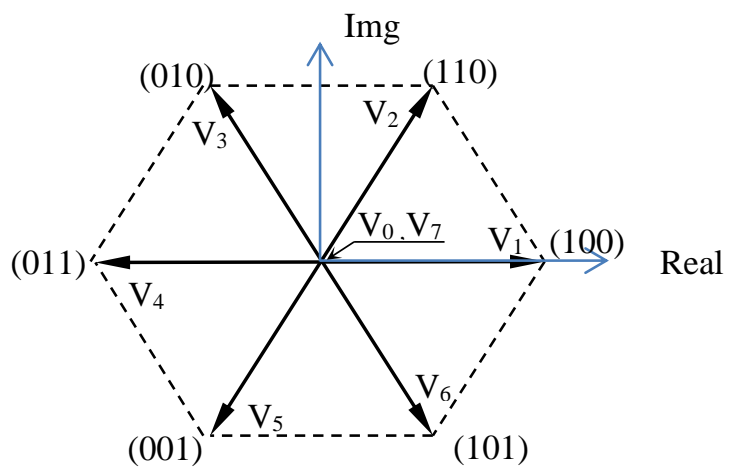

Fig. 6. Voltage vectors of the three-phase VSI

The output voltages of the inverter are expressed as follows

$$
\begin{aligned}
& V_{a}=\left(2 \mathrm{Q}_{1}-\mathrm{Q}_{2}-\mathrm{Q}_{3}\right) * \mathrm{v}_{o} / 3 \\
& V_{b}=\left(2 Q_{2}-Q_{1}-Q_{3}\right) * v_{o} / 3 V_{c}=\left(2 \mathrm{Q}_{3}-\mathrm{Q}_{1}-\right. \\
& \left.\mathrm{Q}_{2}\right) * \mathrm{v}_{o} / 3
\end{aligned}
$$

Table 1 presents the three phase voltages $\mathrm{V}_{\mathrm{A}}, \mathrm{V}_{\mathrm{B}}$ and $\mathrm{V}_{\mathrm{C}}$ expressed with the input voltage of the inverter for the eight different switching states.

Table 1. Voltages $\mathrm{V}_{\mathrm{A}}, \mathrm{V}_{\mathrm{B}}$ and $\mathrm{V}_{\mathrm{C}}$

\begin{tabular}{|c|c|c|c|}
\hline $\begin{array}{c}\text { Switch } \\
\mathrm{ON}\end{array}$ & $\mathrm{V}_{\mathrm{A}}$ & $\mathrm{V}_{\mathrm{B}}$ & $\mathrm{V}_{\mathrm{C}}$ \\
\hline $1,4,6$ & $\frac{2}{3} v_{o}$ & $-\frac{1}{3} v_{o}$ & $-\frac{1}{3} v_{o}$ \\
\hline $1,3,6$ & $\frac{1}{3} v_{o}$ & $\frac{1}{3} v_{o}$ & $-\frac{2}{3} v_{o}$ \\
\hline $2,3,6$ & $-\frac{1}{3} v_{o}$ & $\frac{2}{3} v_{o}$ & $-\frac{1}{3} v_{o}$ \\
\hline $2,3,5$ & $-\frac{2}{3} v_{o}$ & $\frac{1}{3} v_{o}$ & $\frac{1}{3} v_{o}$ \\
\hline $2,4,5$ & $-\frac{1}{3} v_{o}$ & $-\frac{1}{3} v_{o}$ & $\frac{2}{3} v_{o}$ \\
\hline $1,4,5$ & $\frac{1}{3} v_{o}$ & $-\frac{2}{3} v_{o}$ & $\frac{1}{3} v_{o}$ \\
\hline
\end{tabular}

\begin{tabular}{|l|l|l|l|}
\hline $1,3,5$ & 0 & 0 & 0 \\
$2,4,6$ & & & \\
\hline
\end{tabular}

The phase to neutral output voltages of the inverter are expressed as follows:

$$
\begin{aligned}
V_{a}=\frac{2}{3} V_{A}-\frac{1}{3}( & \left.V_{B}+\mathrm{V}_{C}\right) \\
V_{b}= & \frac{2}{3} V_{B}-\frac{1}{3}\left(V_{A}+\mathrm{V}_{C}\right) \\
V_{c} & =\frac{2}{3} V_{C}-\frac{1}{3}\left(V_{B}+V_{A}\right)
\end{aligned}
$$

\subsection{Traction motor}

DC motor, PMSM and Induction Motor (IM) are the major kinds of electric traction motors used for EVs [43]. IM are widely used because they present, low cost and an ease maintenance [44-45], IM proposed to drive an EV in order to have the minimum cost, small volume, lightweight and high efficiency [43]. In [446], a comparison between the performance of IM and the PMSM is given. In [47-48], the authors show that the induction motors will be more used for EV traction.

The mathematical model of the IM in $d-q$ transformation is given by the following equations:

$$
\begin{array}{r}
V_{s}=R_{s} I_{s}+\frac{d \phi_{s}}{d t} \\
V_{r}=R_{r}+\frac{d \phi_{r}}{d t}-j \omega_{r} \phi_{r} \\
\phi_{s}=L_{s} i_{s}+L_{m} i_{r} \\
\phi_{r}=L_{r} i_{r}+L_{m} i_{s}
\end{array}
$$

The stator flux estimation in $d-q$ axis can be expressed as follows:

$$
\begin{array}{r}
\phi_{d s}=\int\left(V_{\mathrm{ds}}-R_{s} i_{d s}\right) d t \\
\phi_{q s}=\int\left(V_{\mathrm{qs}}-R_{s} i_{q s}\right) d t \\
\left|\phi_{s}\right|=\sqrt{{\phi_{d_{s}}{ }^{2}+\phi_{q_{s}}{ }^{2}}^{\theta_{\phi s}}=\tan ^{-1}\left(\frac{\phi_{q_{s}}}{\phi_{d_{s}}}\right)}
\end{array}
$$

The electromagnetic torque is expressed by:

$$
T_{e m}=\frac{3}{2} \cdot \frac{p}{2}\left(\phi_{d s} i_{q s}-\phi_{q s} i_{d s}\right)
$$

Where:

$R_{s}:$ stator resistances

$R_{r}$ :rotor resistance

$L_{s}:$ stator Inductance 
$L_{r}:$ rotor Inductance

$L_{m}$ :mutual inductance

$V_{s}$ :stator voltage

$V_{r}:$ rotor voltage

$p$ : number of poles

$\phi_{r}$ :rotor flux

$\phi_{s}:$ stator flux

$\omega_{r}:$ rotor angular speed

\section{Proposed Fuzzy Sliding Mode controller}

For the fuzzy sliding mode controller, we propose the sliding surface $S_{j}$ described by the equation (22), for $j=1,2,3,4$.

$S_{j}=k_{j} e_{i_{j}}+\lambda e_{v}$

where

$k_{j}$ and $\lambda$ are coefficients used for the sliding surface.

$e_{v}$ represents the voltage error for the bidirectional DC-DC converter described as follows:

$e_{v}=V_{\text {ref }}-v_{0}$

$V_{\text {ref }}$ and $v_{0}$ are respectively the reference and the output voltage for the studied converter.

$e_{i j}$ represents the inductor current error in each cell of the multiphase interleaved bidirectional DC-DC converter. It is expressed as follows:

$e_{i_{j}}=I_{\text {ref }}-i_{L_{j}}$

Thus, for the four converters we have the four follows surfaces

$\left\{\begin{array}{l}S_{1}=k_{1} e_{i_{1}}+\lambda e_{v}=k_{1}\left(I_{\text {ref }}-i_{L_{1}}\right)+\lambda\left(V_{\text {ref }}-v_{0}\right) \\ S_{2}=k_{2} e_{i_{2}}+\lambda e_{v}=k_{2}\left(I_{\text {ref }}-i_{L_{2}}\right)+\lambda\left(V_{\text {ref }}-v_{0}\right) \\ S_{3}=k_{3} e_{i_{3}}+\lambda e_{v}=k_{3}\left(I_{\text {ref }}-i_{L_{3}}\right)+\lambda\left(V_{\text {ref }}-v_{0}\right) \\ S_{4}=k_{4} e_{i_{4}}+\lambda e_{v}=k_{4}\left(I_{\text {ref }}-i_{L 4}\right)+\lambda\left(V_{\text {ref }}-v_{0}\right)\end{array}\right.$

Then, we consider the Lyapunov function $V$ defined as follows:

$V_{j}=\frac{1}{2} S_{j}^{2}$

To make each surface $S_{j}$ attractive and to assure the stability of the system, $\dot{V}_{j}$ must be negative.

Such condition leads to the following inequality:

$S_{j} \dot{S}_{j}<0$

The studied fuzzy sliding control uses the surface $S_{j}$ and $\dot{S}_{j}$ to explain the changes on the output control signal and to insure the Lyapunov stability condition $S_{j} \dot{S}_{j}<0$.

The surface $S_{j}$ and its variation $\dot{S}_{j}$ are the inputs of the proposed controller.

Figure 7 and figure 8 present respectively the membership functions of the surface and its variation. Triangular and trapezoidal membership functions, represented by NB (Negative BIG), NM (Negative Middle) Z (Zero), PM (Positive Middle), and PB (Positive BIG) are used in the normalized domain[-11]for the both inputs.

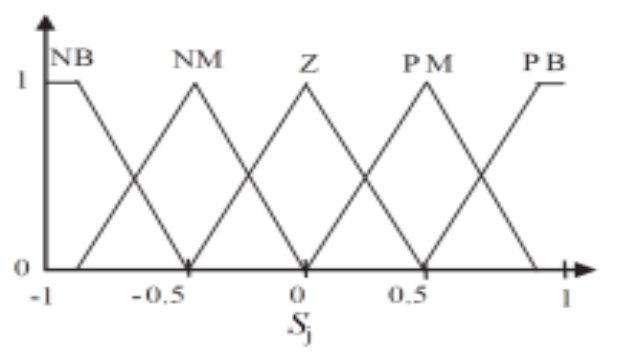

Fig. 7. Surface $S_{j}$ membership functions

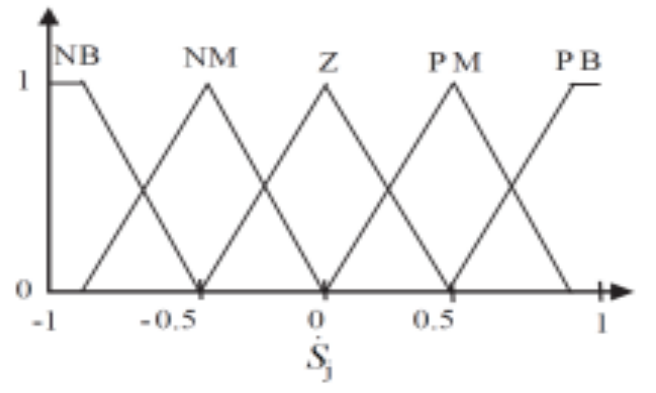

Fig. 8. Surface change $\dot{S}_{j}$ membership functions

The output signal is the control increment $\Delta U(k)$ which is used to update the control law. It is defined as follows:

$U(k)=\Delta U(k)+U(k-1)$

Figure 9 shows the output signal. Five normalized singletons denoted by NB, NM, Z, PM and PB are used for the output $\operatorname{signal} \Delta U$.

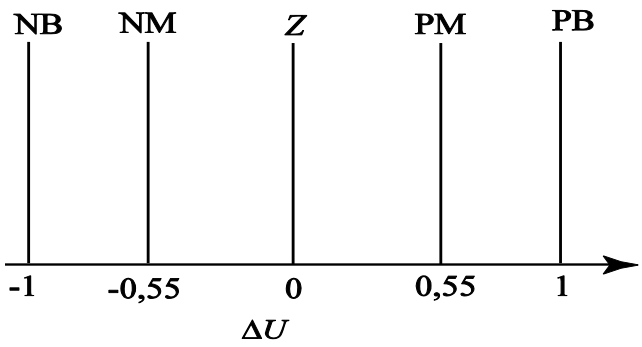

Fig. 9.Output singletons

The rules base of the proposed FSMC are given in Table 2.

Table 2. Rules base of the proposed FSMC

\begin{tabular}{|c|c|c|c|c|}
\multicolumn{1}{c}{$S_{j}$} \\
\hline NB & NM & Z & PM & PB \\
\hline
\end{tabular}




\begin{tabular}{c|c|c|c|c|c|c|}
\hline \multirow{5}{*}{$\dot{S}_{j}$} & $\mathrm{~PB}$ & $\mathrm{Z}$ & $\mathrm{PM}$ & $\mathrm{PB}$ & $\mathrm{PB}$ & $\mathrm{PB}$ \\
\cline { 2 - 7 } & $\mathrm{PM}$ & $\mathrm{NM}$ & $\mathrm{Z}$ & $\mathrm{PM}$ & $\mathrm{PB}$ & $\mathrm{PB}$ \\
\cline { 2 - 7 } & $\mathrm{Z}$ & $\mathrm{NB}$ & $\mathrm{NM}$ & $\mathrm{Z}$ & $\mathrm{PM}$ & $\mathrm{PB}$ \\
\cline { 2 - 7 } & $\mathrm{NM}$ & $\mathrm{NB}$ & $\mathrm{NB}$ & $\mathrm{NM}$ & $\mathrm{Z}$ & $\mathrm{PM}$ \\
\hline & $\mathrm{NB}$ & $\mathrm{NB}$ & $\mathrm{NB}$ & $\mathrm{NB}$ & $\mathrm{NM}$ & $\mathrm{Z}$ \\
\hline
\end{tabular}

\section{Simulation Results}

The multiphase phase interleaved bi-directional DC-DC converter described above, was simulated and controlled using the proposed fuzzy sliding mode control. Figure 10 presents the inductors currents ( $\mathrm{i}_{\mathrm{L} 1}, \mathrm{i}_{\mathrm{L} 2}, \mathrm{iL}_{3}$ and $\mathrm{i}_{\mathrm{L} 4}$ ) of the 4 interleaved bidirectional DC-DC converters.

Figures 11 and 12 present the steady state of the three phase output inverter currents waveforms and the output voltage between phase A and Phase B, respectively.

Figure 13 shows the transient step response of the output voltage for multiphase interleaved bi-directional DC-DC converter for the boost mode when the settling voltages is $340 \mathrm{~V}$.

Figure 14 presents the variation of the current absorbed by the three phases induction machine at 0.08 s. In figure 15 we can notice that the proposed FSMC rejects such perturbation.

Figure 16 proves that the output voltage for the multiphase interleaved bi-directional DC-DC converter still at the same desired value despite the variation of the motor speed at $1.1 \mathrm{~s}$ (figure 17).

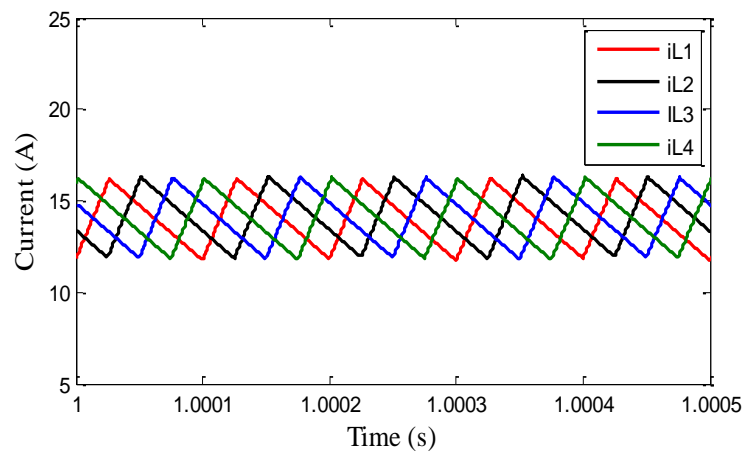

Fig. 10. Inductors currents waveforms of the 4 interleaved bidirectional DC-DC converter.

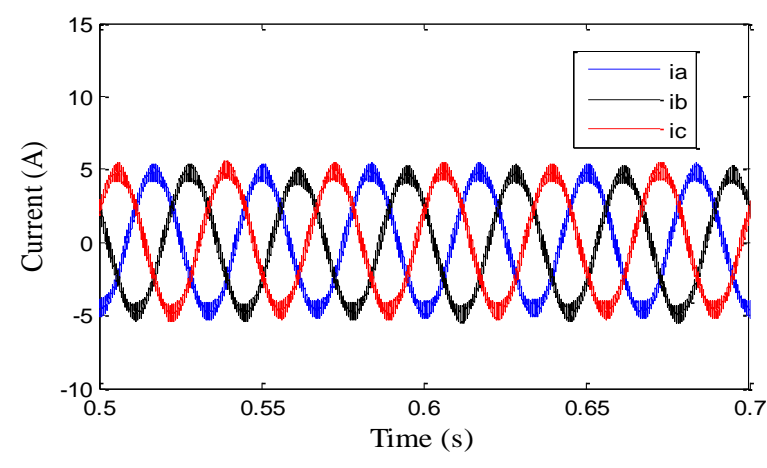

Fig. 11. Three phase output inverter currents evolution.

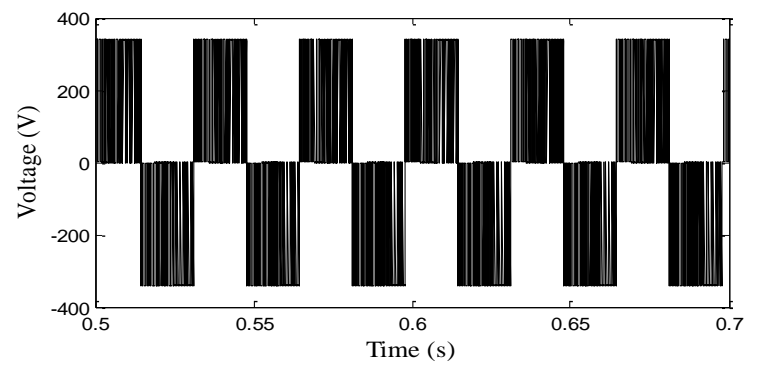

Fig. 12. Output voltage inverter waveforms between phase A and Phase B.

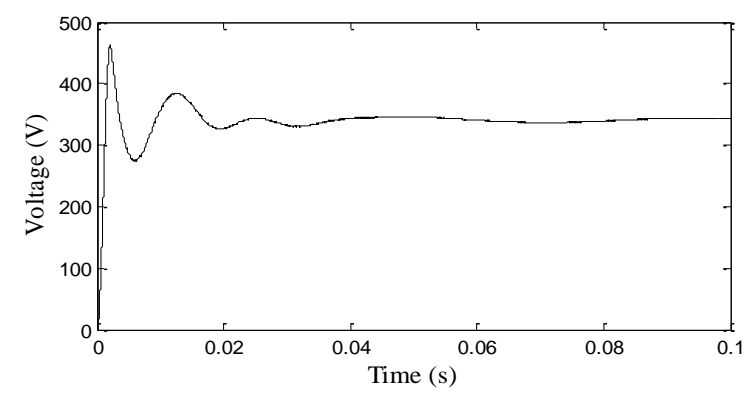

Fig. 13. Step voltage responses

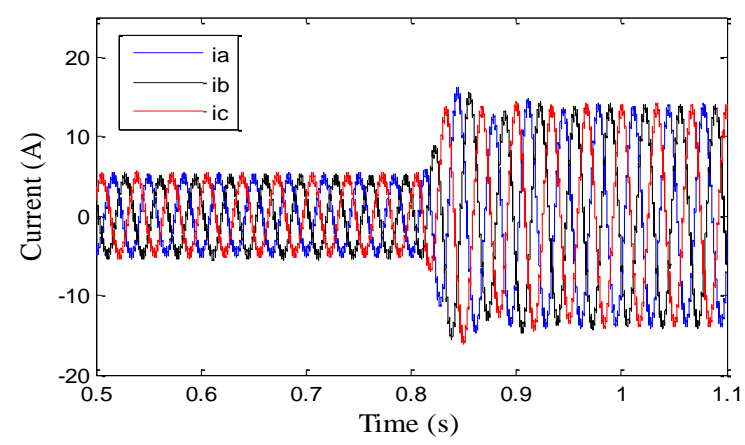

Fig. 14. Evolution of the three phase induction machine currents 


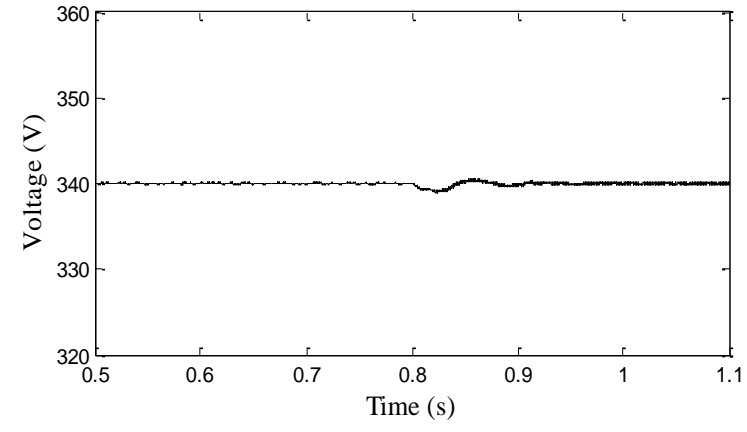

Fig. 15. Output voltage evolution of the multiphase interleaved bi-directional DC-DC Converter for the case of the three phase induction machine current variation

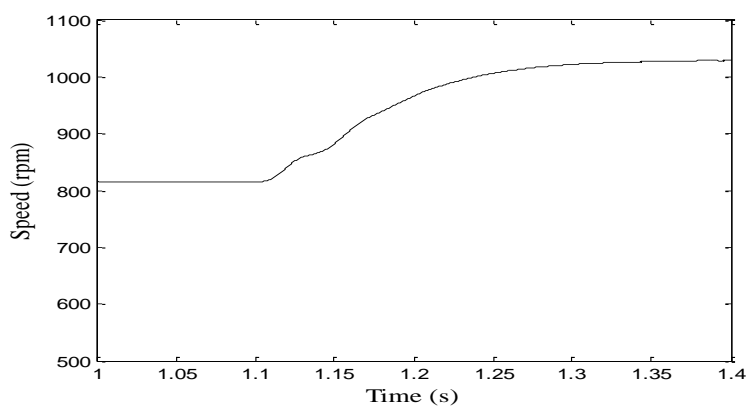

Fig. 16. Evolution of the motor speed

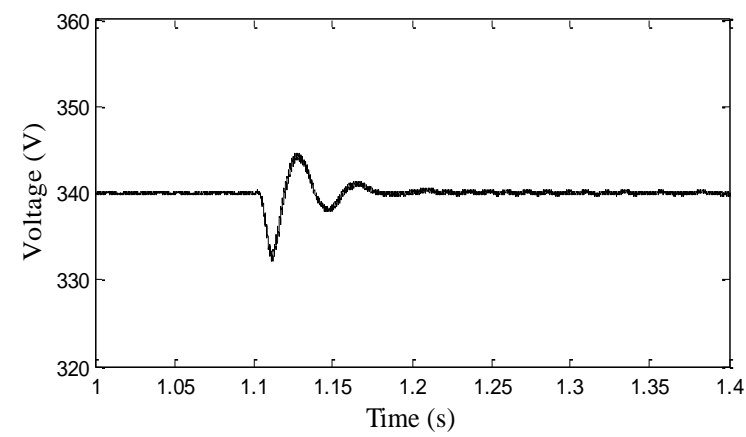

Fig. 17. Output voltage evolution of the multiphase interleaved bi-directional DC-DC Converter for the case of motor speed variation

\section{Conclusions}

This paper proposes new control law for multiphase interleaved bidirectional DC-DC converters in order to increase and to regulate the battery voltage from low side voltage to high side voltage, which is necessary to feed the inverter and the motor traction for EV applications. Therefore, a Fuzzy sliding mode control is proposed in order to increase the performance of the high side voltage and to have an equal load current share between each converter module.
The proposed method is tested by simulation. The obtained results show the robustness of the proposed FSMC against the variation of the speed and the current of the used traction motor. This work can be extended to study the connection of the EV to a smart grid.

\section{References}

[1] Z. Xuhui, X. Wen, Z. Feng, G. Xinhua, "A new control strategy for bidirectional DC-DC converter in electric vehicle", Proc. Int. Conf. Elect. Mach. Syst. (ICEMS), pp. 1-4, Aug. 2011.

[2] L. Zhu, "A novel soft-commutating isolated boost full-bridge ZVS-PWM DC-DC converter for bidirectional high power applications," IEEE Transactions on Power Electronics, vol. 21, no. 2, pp. 422-429, March 2006

[3] V. F. Pires, D. Foito, A. Cordeiro and J. F. Silva, "A Single-Switch DCDC Buck-Boost Converter with Extended Output Voltage", Proc. 7th International Conference on Renewable Energy Research and Applications (ICRERA), pp. 791-796, 14-17 Oct. 2018

[4] H. Kim, C. Yoon, and S. Choi, "A Three-Phase Zero-Voltage and ZeroCurrentSwitching DC-DC Converter for Fuel Cell Applications," IEEE Transactions on Power Electronics, vol. 25, no.2, pp. 391-398. February 2010.

[5] S.Gargies, H. Wu, and C. Mi, "Design and control of an isolated bidirectional dc-dc converter for hybrid electric vehicle applications," Journal of Asian Electric Vehicles, vol. 4, no. 1, pp 851-856, 2006.

[6] J. Zeng, W. Qiao, and L. Qu, "An Isolated Three-Port Bidirectional DCDC Converter for Photovoltaic Systems with Energy Storage," IEEE transactions on Industrial Electronics, vol. 51, no. 4, pp. 3493-3503, August 2015.

[7] Y. Du, X. Zhou, S. Bai, S. Lukic and A.Huang, "Review of non-isolated bi-directional DC-DC converters for plug-in hybrid electric vehicle charge station application at municipal parking decks," Twenty-Fifth Annual IEEE Applied Power Electronics Conference and Exposition (APEC), pp.1145-1151, 21-25 February 2010 .

[8] L. Kumar, and S. Jain, "A multiple input dc-dc converter for interfacing of battery/ultracapacitor in EVs/HEVs/FCVs," IEEE $5^{\text {th }}$ India International Conference on Power Electronics, pp.1-6, December 2012.

[9] S. Ikeda and F. Kurokawa, "Isolated and wide imput ranged boost full bridge DC-DC converter for improved resilience of renewable energy systems", Proc. 6th International Conference on Renewable Energy Research and Applications (ICRERA), pp. 290-295, 5-8 Nov. 2017.

[10] E.Ali, Y. Lee and R.Kaushik, "Power Electronics and Motor Drives in Electric, Hybrid Electric, and Plug-In Hybrid Electric Vehicles, " IEEE Trans. Ind. Electron., Vol. 55, No. 6, pp. 2237-2245, June, 2008.

[11] J. Silvestre, "Half-bridge bidirectional DC-DC Converter for small Electric Vehicle," IEEE International Symposium on Power Electronics, Electrical Drives, Automation and Motion, pp. 884-888, 11-13 June 2008.

[12] H. Ardi, A. Ajami, F. Kardan, S. N. Avilagh, "Analysis and Implementation of a Nonisolated Bidirectional DC-DC Converter with High Voltage Gain", IEEE Trans. Ind. Electron., vol. 63, no. 8, pp. 48784888, August 2016.

[13] K. Tytelmaier, O. Husev, O. Veligorskyi, R. Yershov, "A review of nonisolated bidirectional DC-DC converters for energy storage systems", Proc. $2^{\text {nd }}$ Int. Young Scientists Forum on Applied Physics and Engineering, pp. 22-28, 10-14 October 2016.

[14] E. Ribeiro, A.J.M. Cardoso, C. Boccaletti, "Fault Diagnosis in NonIsolated Bidirectional Half-Bridge DC-DC Converters," IECON, 40th Annual Conference of the IEEE Industrial Electronics Society, pp. 4458 - 4463, October 2014.

[15] A. Jaya, and A. M Jain, "Design Modelling and Control of Bidirectional DC-DC Converter for EV," IEEE International Conference on Emerging Research in Electronics, Computer Science and Technology (ICERECT), pp. $294-297,2015$. 
[16] R. M. Schupbach and C. Bald, "Comparing DC-DC Converters for Power Management in Hybrid Electric Vehicles," in IEEE International Electric Machines and Drives Conference, vol.3, pp.1369-1374, 2003.

[17] N. Liqin, D. J. Patterson, and J. L. Hudgins, " High power current sensorless bidirectional 16-phase interleaved DC-DC converter for hybrid vehicle application," IEEE Transactions on Power Electronics, vol.27 no.3, pp.1141-1151, March 2012.

[18] G. Niyitegeka, E. M. Harerimana, G. Park and J. Choi, "Phase shift modulation and DC-link's voltage balancing control for DAB DC-DC converter", Proc. of IEEE ICSG'2018, pp. 70-75, Dec. 2018.

[19] O. Garcia, P.Zumel, A. de Castro, P. Alou, J.A. Cobos, "Current SelfBalance Mechanism in Multiphase Buck Converter," Power Electronics, IEEE Transactions on, vol.24, no.6, pp: 1600 - 1606, June 2009.

[20] D.P. Urciuoli and C.W. Tipton, "Development of a $90 \mathrm{~kW}$ bi-directional dc-dc converter for power dense applications," in Proc. IEEE APEC, Dallas, TX, pp. 1375-1378, March 2006

[21] H. Xu, X. Wen, E. Qiao, X. Guo, and L. Kong, "High power interleaved boost converter in fuel cell hybrid electric vehicle," in Proc. IEEE IEMDC, San Antonio,TX, pp. 1814-1819, May 2005.

[22] O.Garcia, P. Zurnel, A. de Castro, and A. Cobos, "Automotive dc-dc bidirectional converter made with many interleaved buck stages," IEEE Trans. Power Electron., vol. 21, no. 3, pp. 578-586, May 2006.

[23] A. Consoli, G. Scarcella, G. Giannetto, and A. Testa, "A multiphase DC/DC converter for automotive dual voltage power systems," Industry Applications Magazine, IEEE, Vol.10, Issue 6, pp. 35-42, November/December 2004.

[24] B. Choi, "Comparative Study on Paralleling Schemes of Converter Modules for Distributed Power Applications," IEEE Trans. Industrial Electronics, vol. 45, no. 2, pp. 194-199, April 1998.

[25] X. Huang, X. Wang, T. Nergaard, J.-S. Lai, X. Xu, L. Zhu, "Parasitic ringing and design issues of digitally controlled high power interleaved boost converters," IEEE Trans. Power Electron., vol. 19, no. 5, pp. 13411352, September 2004.

[26] J. Zhang, R. Y. Kim, and J.-S. Lai, "High-power density design of a softswitching high-power bidirectional dc-dc converter," in Proc. IEEE PESC, Jeju, Korea, pp. 2119-2125, June 2006.

[27] S. Kanta, B. Plangklang and W.Subsingha, "Design of a Bi-directional DC-DC 4 Phase Interleave Converter for PV Applications," 11th EcoEnergy and Materials Science and Engineering, vol. 56, pp. 604-609, 2014.

[28] D. Xu, C. Zhao, and H. Fan, "A PWM plus phase-shift control bidirectional dc-dc converter," IEEE Trans. Power Electron., Vol. 19, no.3, pp. 666 - 675, May 2004.

[29] J. H. Lee, D. Y. Jung, T. K. Lee, Y. R and Kim, C. Y. Won, "Regenerative Current Control Method of Bidirectional DC/DC Converter for EV/HEV Application," Journal of Electrical Engineering and Technology, vol. 8, pp. $97-105,2013$.

[30] S. Bal, A. K. Rathore, and D. Srinivasan, "Naturally Commutated Current-fed Three-Phase Bidirectional Soft-switching DC-DC Converter with $120^{\circ}$ Modulation Technique," IEEE Transactions on Industry Applications, Vol.52, no. 3, pp. 4354 - 4364, Sept.-Oct. 2016.

[31] T.Kim, J.Lee, and C.Won, "Design and Control Methods of Bidirectional DC-DC Converter for the Optimal DC-Link Voltage of PMSM Drive," Journal of Electrical Engineering and Technology, vol. 9, no. 6, pp.1944-1953, 2014.

[32] X. Liu, J. Deng, Y-F. Liu and P. Yang, "Research and Simulation of Parallel Current-Mode Controlled Buck Converter," Proc. of the 3rd IEEE Conference on Industrial Electronics and Applications ICIEA 2008, pp. 423-428, Singapore, 3-5 June 2008.

[33] K. Suryanarayana, and HN Nagaraja, "Modeling and design of 700W digital average current mode controlled multiphase bidirectional DC-DC converter," IEEE Asia Pacific Conference on Postgraduate Research in Microelectronics and Electronics, 27-29 November, 2015.

[34] R.J. Wai, and C. Chen, "Automatic Fuzzy Control Design for Parallel DCDC Converters," Proc. of the International Multi-Conference of Engineers and Computer Scientists," IMECS 2009, vol. 1, Hong Kong, 18- 20 March 2009.

[35] A.Sahbani, K.Ben Saad and M.Benrejeb, "Fuzzy sliding mode control for parallel DC-DC Boost converter," International Review of Electrical Engineering (IREE), vol.9, no.2, pp.249-254, January 2014.

[36] X. Dominguez, O. Camacho, P. Leica, and A.Rosales, "A fixed-frequency Sliding-mode control in a cascade scheme for the Half-bridge Bidirectional DC-DC converter," IEEE Ecuador Technical Chapters Meeting (ETCM), October 12-14, 2016.

[37] H. Kahveci, and H.I. Okumus, "A Novel Fuzzy Logic Speed Controller for Brushless DC Motors," ICECCO'12, pp. 167-170, November 2012.

[38] A. M. Omekanda, "Switched reluctance machines for EV and HEV propulsion: State-of-the-art, IEEE Workshop on Electrical Machines Design, Control and Diagnosis (WEMDCD), pp. 70-74, 2013.

[39] S. B. Bahir, A.R. Beig and M. Poshtan, "An improved space vector PWM for grid connected MMC", Proc. 6th International Conference on Renewable Energy Research and Applications (ICRERA), pp. 556-561, 5-8 Nov. 2017.

[40] V. Sugi, E.Chandla, "Implementation of Cascaded H Bridge Inverter Using Space Vector PWM, "International Journal of Advanced Research in Electrical, Electronics and Instrumentation Engineering, vol. 3, no.2, April 2014.

[41] M. S. Hassan and M. Shoyama, "Common-Mode Voltage Investigation and Reduction of Split-Source Inverter", Proc. 2018 Int. Conf. on Smart Grid (icSmartGrid 2018), pp. 118-122, Dec. 2018.

[42] H. Benbouhenni, Z. Boudjemaa and A. Belaidi, "Using three-level Fuzzy space vector modulation method to improve indirect vector control strategy of a DFIG based wind energy conversion systems", International Journal of Smart Grid (ijSmartGrid), Vol.2, No.3, 2018.

[43] M. Bendjedia, K. A. Tehrani, Y. Azzouz and H. Shall, "Robust RST Controller Design for Induction Motor Drive for Electric Vehicle Application," IEEE First International Conference on Green Energy (ICGE), pp 251-258, 2014.

[44] M. Zeraoulia, M. E. H. Benbouzid and D. Diallo, "Electric motor drive selection issues for HEV propulsion systems: a comparative study," IEEE Trans. Veh. Technol., vol. 55, no 6, pp. 1756 -1764, Nov. , 2006.

[45] J. de Santiago, H. Bernhoff, B. Ekergard, S. Eriksson, S. Ferhatovic, R. Waters, and M. Leijon, "Electrical motor drivelines in commercial allelectric vehicles: A review", Vehicular Technology IEEE Transactions on, vol. 61, no. 2, pp. 475-484, Februray 2012.

[46] G. Pellegrino, A. Vagati, B. Boazzo, and P. Guglielmi, "Comparison of induction and PM synchronous motor drives for EV application including design examples, IEEE Transactions on Industry Applications," vol. 48, no. 6, pp. 2322-2332, Nov. , 2012.

[47] X. Shi, and M. Krishnamurthy, "Digital Control of Induction Machines as a Backup Control Strategy for Fault Tolerant Operation of Traction Motors," IEEE Journal of Emerging and Selected Topics in Power Electronics, vol. 2, no. 3, pp. 651-658, Sept. , 2014.

[48] S.Y. Sim, Z. A. Haron, N. M. Zin, W. M. Utomo, A.A. Bohari,and R. M. Ariff., "Neural network SVPWM-DTC of induction motor for EV load model," IEEE Electrical Power, Electronics, Communicatons, Control and Informatics Seminar (EECCIS), pp.23-28, August , 2014. 